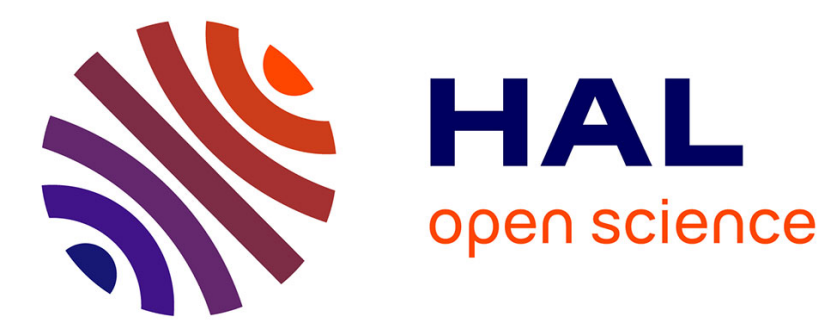

\title{
Market Power and Collusion on Interconnection Phone Market in Tunisia: What Lessons from International Experiences
}

\author{
Sami Debbichi, Walid Hichri
}

\section{> To cite this version:}

Sami Debbichi, Walid Hichri. Market Power and Collusion on Interconnection Phone Market in Tunisia: What Lessons from International Experiences. 2014. halshs-00956638

\section{HAL Id: halshs-00956638 \\ https://shs.hal.science/halshs-00956638}

Preprint submitted on 7 Mar 2014

HAL is a multi-disciplinary open access archive for the deposit and dissemination of scientific research documents, whether they are published or not. The documents may come from teaching and research institutions in France or abroad, or from public or private research centers.
L'archive ouverte pluridisciplinaire $\mathbf{H A L}$, est destinée au dépôt et à la diffusion de documents scientifiques de niveau recherche, publiés ou non, émanant des établissements d'enseignement et de recherche français ou étrangers, des laboratoires publics ou privés. 
Market Power and Collusion on Interconnection Phone Market in Tunisia: What Lessons from International Experiences

Sami Debbichi, Walid Hichri

March 2014 


\section{GATE Groupe d'Analyse et de Théorie Économique Lyon-St Étienne}

93, chemin des Mouilles 69130 Ecully - France

Tel. +33 (0)4 72866060

Fax $+33(0) 472866090$

6, rue Basse des Rives 42023 Saint-Etienne cedex 02 - France

Tel. +33(0)4 77421960

Fax. +33 (0)4 77421950

Messagerie électronique / Email : gate@gate.cnrs.fr

Téléchargement / Download : http://www.gate.cnrs.fr - Publications / Working Papers 


\title{
Market Power and Collusion on Interconnection Phone Market in Tunisia: What Lessons from International Experiences
}

\author{
Sami DEBBICHI * \\ * PhD Student RU: AEDD, Faculty of Economics and Management \\ of Tunis el Manar, Tunisia. \\ Email: sami.debichi @ esct.rnu.tn; Tel: +21622833783
}

\begin{abstract}
Walid HICHRI**
** University of Lyon, F-69007, France; CNRS, GATE Lyon Saint Etienne, 93, Chemin de Mouilles, Ecully, F-69130, France; University Lyon 2, Lyon, F-69007, France;

LAREQUAD; email: hichri@gate.cnrs.fr
\end{abstract}

\begin{abstract}
We try in this paper to characterize the state of mobile phone market in Tunisia. Our study is based on a survey of foreign experience (Europe) in detecting collusive behavior and a comparison of the critical threshold of collusion between operators in developing countries like Tunisia. The market power is estimated based on the work of Parker Roller (1997) and the assumption of "Balanced Calling Pattern". We use then the model of Friedman (1971) to compare the critical threshold of collusion. We show that the "conduct parameter" measuring the intensity of competition is not null during the period 1993-2011. Results show also that collusion is easier on the Tunisian market that on the Algerian, Jordanian, or Moroccan one.
\end{abstract}

Key words: Termination rate; Market power; Competition; Mobile phone Market.

JEL Classification: D41, L96, L71 


\section{Introduction}

Liberalization of the telecommunications sector consists of opening all its segments to competition and privatization (Wallsten (2001)). Economic issues in the telecommunications sector and regulation are very important (Flacher and Jennequin (2007)). In fact, several economic issues are resolved, as the barriers to entry (Baranes and Flochel (1999)), interconnection networks (Bulatovic (2004), Colombier et al. (2010), Schiff (2005)), the level of pricing (Berger (2005), Dessein (2003)), privatization (Wallsten (2002)), market structure (De Donder (2005)) and strategic behavior competitors such as competition (Laffont and Tirole (2002)), collusion (Debbichi and Hichri (2013b), Parker and Roller (1997), Pénard (2003), Souam and Pénard (2002), Berger (2005)), agreement merging (Artz et al. (2009)), entry on the market (Bourreau (2001)) or deviation.

The mobile phone market had known recently a dynamic and changing structure in most of the countries who have undertaken to reform their telecommunications sectors. Depending on the characteristics of the local market (private or public sector) resulting from the restructuration and the implementation of progressive market liberalization policies, the number of actors (duopoly or oligopoly) and consequently their profits in the telecommunications industry has been variable. There are Many European operators active in the Arab markets. That's why we will begin this work by exposing cases of detection of collusion in European countries. We'll then study the degree of competition in the Tunisian market and similar Arab countries.

Studies conducted by The "Arab Advisor Group" show that the Cellular Competition Intensity Index results for April 2011 revealed that Saudi Arabia tops the score as the most competitive Arab market with a $76.01 \%$ mark followed by Jordan $(75.37 \%)$, in the $6^{\text {th }}$ rank Morocco $(64.72 \%)$, Tunisia $(63.23 \%)$ ranked $8^{\text {th }}$, and Algeria $(61.17 \%)$ who was ranked $9^{\text {th }}$. The Cellular Competition Intensity Index is relative in nature as it compares the state of every market relatively to other markets. Consequently, even if a market's absolute level of competition improved, its score in this relative index will also depend on at which level other markets are developed.

In this work, we will first present microeconomic models dealing with market competition and the preference for collusion of operators on interconnected markets. Our goal is to study the state of mobile phone market in Tunisia and to compare the preference for collusion through the threshold value with three Arabian markets that are Morocco, Algeria and Jordan, in duopoly and oligopoly structures, where the actors are private, mixed or public. The market power will be estimated, based on the work of Parker and Roller (1997) and on the assumption of "Balanced Calling Pattern". The comparison of the critical threshold of preference for collusion will be based on the model of Friedman (1971).and the results of Cortade (2005) and Debbichi and Hichri (2013a). Our findings can be used by the decision makers to control collusion, by acting on the level of interconnection fees for each market structure and by implementing the suitable market liberalization policies in this sector.

Interconnection is a key factor for competition (Laffont et al. (1996)). Each operator must pay an interconnection charge to its competitor for routing the call on its network (twoway interconnection) (Baranes and Poudou (2010), Bulatovic (2004)). The stability of the interconnection rate leads us to ask about the state of competition, firstly, on the interconnection market and, secondly, on the retail market (Parsons (2002)). In this context, collusion is one of the possibilities and strategies (Colombier et al. (2010)) that actors may 
adopt to control the market. Collusion is a strategic behavior chosen by economic agents when it allows better results in comparison to competition. Several studies have already highlighted the determinants of the choice of colluding (Parker and Roller (1997) and Hoffler (2009)), and especially its relationship with the level of interconnection fees. Also, telecommunications operators may even use a high access charge as an instrument of collusion (Dessein (2003)). Laffont and Tirole (2000) present a study of competition in telecommunications. In the same context, a view of this competition from the United States was presented by Parsons (2002).

The paper is organized as follows: Section 1 presents the European cases detecting collusive behavior. In Section 2, we extend the work of Debbichi and Ben Khalifa (2013) to study the structure and state of the mobile phone market in Tunisia. The results of Debbichi and Hichri (2013a) related to the model of Friedman (1971) are presented in Section 3. These theoretical results will be applied to different countries and cases following several market structures and presented in section 4. Finally, we present concluding remarks.

\section{The European cases:}

On a practical level and starting international experiences, several regulatory frameworks were able to detect these collusive behaviors and their natures, enhancing the damage incurred by the economy and to impose sanctions on operators due to these injuries. The cases of French and Czechs operators and even other operators of the European Union have the best-known cases worldwide. Detection instruments, the nature, scope and level of damage varies from one country to another.

On the mobile phone market, factors that facilitate the implementation of collusive behavior are: exchange of information, convergence of market shares, the monetary transfer between operators and communication between them through regular meetings (Pénard (2002)). These factors are risky for possible collusion, as it is the case of operators of mobile phone in France.

Indeed, they have implemented two types of cartel practices to restrict competition: exchanges of strategic information (these practices may facilitate collusion in the first row) and agreement between 2000 and 2002 to stabilize their market shares. This information exchange reduces the intensity of competition in the mobile market for a main reason: on a market where the entry is very difficult, the exchange of information of this type is likely to affect competition. Consultations in order to stabilize their market share has been established through the intersection of several major indexes, accurate and consistent, such as the existence of handwritten documents explicitly mentioning an "agreement" (explicit collusion), as well as similarities identified during this period in the trade policies of operators, particularly in terms of acquisition costs and pricing of communications. The Competition Council has therefore fined the three mobile operators, Orange France, SFR and Bouygues Telecom respectively amounting to $€ 256$ millions, $€ 220$ millions and $€ 58$ millions.

Collusion may be related to price, quality of service and technical standardization networks. The establishment of such a practice is done through regular meetings of leaders. This is the case between "Deutsche Telekom", "France Telecom", "Telecom Italia", "Telefonica" and "Vodafone" convicted of monopolistic agreement after secret meetings, four meetings in fifteen months, October 2010 in Paris, February 2011 in Barcelona, July 2011 in Venice and on January in London. This is the subject that could be investigated by 
the European Commission concerning a possible collusion between them, including the standards for future mobile communication services.

\section{The mobile phone market in Tunisia: Structure and Market Power:}

Tunisia has one of the more developed mobile markets in Africa as indicated by the high level of mobile penetration. There are three mobile phone operators in the country. The market structure of the mobile phone in Tunisia has gone through several stages, from the monopolistic structure (1992-2001), to the duopolistic one (2002-2009) until reaching a three operators structure (from 2010 until today). In addition to the market structure, there have been changes in the market shares of the public and the private operators. Indeed, the privatization of Tunisia Telecom (T.T.) (the historical national operator) in 2006 transformed (theoretically) the market from a mixed (Private-Public) duopoly to a private one. With the entry of Orange Tunisia on the market in 2010, one should talk about a three private operators market. Obviously, the preference for collusion is certainly not the same in these different market structures. At the same time, some changing in the market structure was the result of a strategic behavior adopted by the several economic operators. In this context, collusion is one of the possibilities and strategies (Colombier et al. (2010)) that actors may adopt to control the market and practice market power. Latter is the ability to profitably alter prices away from the competitive price. It is measured often by the Lerner index.

We suppose that an operator has a real market power if it sets non-competitive prices above marginal cost. In absence of cost accounting, the measurement of the marginal cost will be more difficult and assessment of market power will become impossible. For this reason, Parker and Roller (1997) consider "the conduct parameter" $\vartheta$, defined by:

$$
\begin{gathered}
a\left(q_{i j}\right)+\vartheta \dot{a}\left(\mathrm{q}_{\mathrm{ij}}\right) \mathrm{q}_{\mathrm{ij}}=\theta_{\mathrm{i}} \\
a\left(q_{i j}\right)-\theta_{\mathrm{i}}=-\vartheta \dot{a}\left(\mathrm{q}_{\mathrm{ij}}\right) \mathrm{q}_{\mathrm{ij}} \Leftrightarrow \vartheta=\left(\frac{-1}{a ́\left(\mathrm{q}_{\mathrm{ij}}\right) \mathrm{q}_{\mathrm{ij}}}\right)\left(a\left(q_{i j}\right)-\theta_{\mathrm{i}}\right) \\
\vartheta=\left(\frac{-a}{a\left(q_{i j}\right) q_{i j}}\right)\left(\frac{a\left(q_{i j}\right)-\theta_{i}}{a\left(q_{i j}\right)}\right) \Leftrightarrow \vartheta=e L
\end{gathered}
$$

where $q_{i j}$ is the quantity of interconnection exchanged between two networks, $\theta_{i}$ is the marginal cost, $a$ is the termination price, and $e$ represents the demand elasticity of interconnection. The price elasticity of demand is assumed constant $(8 \%)$ during the period 2002-2011 for both operators, is calculated from the following formula and based on the hypothesis "Balanced Calling Pattern"l (Debbichi and Ben Khalifa (2013)):

\footnotetext{
${ }^{1}$ Laffont and Tirole (2000) define this hypothesis as the fact that fraction of calls that is generated on one network and that ends on the other competing network is proportional to the market share of the latter. In other words, the flow of incoming and outgoing calls is balanced even if market shares are not.
} 


$$
e a \backslash q=\frac{\frac{a^{1}-a^{0}}{a^{0}}}{\frac{q_{12}^{1}-q_{12}^{0}}{q_{12}^{0}}}
$$

The Lerner index (margin) $L$ of one operator is equal to its market share divided by demand elasticity (request to interconnection) and is given by the following expression ${ }^{2}$ :

$$
\frac{\left(a\left(q_{i j}\right)-\theta_{i}\right)}{a\left(q_{i j}\right)}=\frac{\propto_{i}}{e}=L_{i}
$$

The Herfindahl-Hirschman Index $(H H I)$ is defined as the sum of the squared market shares:

$$
H H I=\sum_{i=1}^{n} \alpha_{i}^{2}
$$

and

$$
\begin{gathered}
\bar{L}=\sum_{i=1}^{n} \alpha_{i} L_{i} \\
\Leftrightarrow \bar{L}=\sum_{i=1}^{n} \alpha_{i}\left(\frac{a-\theta_{\mathrm{i}}}{a}\right)=\left(\frac{a-\bar{\theta}_{1}}{a}\right)
\end{gathered}
$$

The average index is equal to $\bar{L}=\left(\frac{a-\overline{\theta_{1}}}{a}\right)$ where $\bar{\theta}=\sum_{i=1}^{2} \alpha_{i} \theta_{\mathrm{i}}$ is the weighted average unit cost of interconnection service.

Moreover, as $\frac{\left(a\left(q_{i j}\right)-\theta_{i}\right)}{a\left(q_{i j}\right)}=\frac{\alpha_{i}}{e}$ this average value is also given by:

$$
\bar{L}=\sum_{i=1}^{n} \frac{\alpha_{i}^{2}}{e}=\frac{H H I}{e}
$$

The average Lerner index is proportional to the $H H I$ on the interconnection market. We are faced with two alternatives; $\vartheta \rightarrow 0$ (perfect competition of interconnection market) and $\vartheta \rightarrow 1$ (the market is monopolistic). Generally, in the case of Cournot competition between $n$ symmetric operators, $\vartheta \rightarrow \frac{1}{n}$. The parameter $\vartheta$ measures then the degree of collusion. In this case it's possible to construct an econometric test to reject or to accept the assumption according to which the industry is (or not) competitive, and to compare the theoretical values to the estimated ones.

If $\vartheta=0$, then $a=\theta$ and prices are equal to marginal costs, which means that the industry is perfectly competitive. situation.

If $\vartheta>0$, then the prices are above marginal costs and the industry is in a collusive

\footnotetext{
${ }^{2}$ For More details see Debbichi and Ben Khalifa (2013).
} 
Table 1 (Debbichi and Ben Khalifa (2013)) presents values of market power (20022010) during the duopoly era. We will retain these values and complete the study of two eras: monopoly (1993-2001) and oligopolistic in 2011.

Table 1 : Tunisian Market Power value (1993-2011)

\begin{tabular}{lccc}
\hline Years & Market power value & Years & Market power value \\
\hline $\mathbf{1 9 9 3}$ & $1.00^{* 3}$ & $\mathbf{2 0 0 3}$ & 0.6058 \\
$\mathbf{1 9 9 4}$ & $1.00^{*}$ & $\mathbf{2 0 0 4}$ & 0.5848 \\
$\mathbf{1 9 9 5}$ & $1.00^{*}$ & $\mathbf{2 0 0 5}$ & 0.5103 \\
$\mathbf{1 9 9 6}$ & $1.00^{*}$ & $\mathbf{2 0 0 6}$ & 0.5024 \\
$\mathbf{1 9 9 7}$ & $1.00^{*}$ & $\mathbf{2 0 0 7}$ & 0.5014 \\
$\mathbf{1 9 9 8}$ & $1.00^{*}$ & $\mathbf{2 0 0 8}$ & 0.5002 \\
$\mathbf{1 9 9 9}$ & $1.00^{*}$ & $\mathbf{2 0 0 9}$ & 0.5018 \\
$\mathbf{2 0 0 0}$ & $1.00^{*}$ & $\mathbf{2 0 1 0}$ & 0.4580 \\
$\mathbf{2 0 0 1}$ & $1.00^{*}$ & $\mathbf{2 0 1 1}$ & $0.3333^{*}$ \\
$\mathbf{2 0 0 2}$ & 0.6058 & & \\
\hline
\end{tabular}

In the table above, values marked by asterisks are not estimated by the conduct parameter, but using the equation $\vartheta=\frac{1}{n}$ with $n=1$ (Number of operators) in (1993-2001) and $n=3$ after 2010. We deduce that $\vartheta \rightarrow \frac{1}{n}=\frac{1}{2}>0$ and that the interconnection price is above marginal cost. This result is valid for the three structures of the Tunisian market (monopoly, duopoly and triopoly). However, the intensity of market power decreases when the number of operators on the market increases. An econometric analysis of market power on the Tunisian mobile industry is presented in Debbichi (2014).

Debbichi and Hichri (2013a) present a Cournot model that compares the intensity of market power using the critical threshold of collusion in duopoly and oligopoly Markets, where the actors are private, mixed or public. Their findings can be used by the decision makers to control collusion by acting on the level of interconnection fees for each market structure and by implementing the suitable market liberalization policies in this sector. An example of the market power applied to the case of The U.S Airline Industry can be found in Murakami and Asahi (2011).

\section{The Results of Debbichi and Hichri (2013a) based on the model of Friedman (1971):}

In this section, we present the theoretical results of Debbichi and Hichri (2013a), based on the model of Friedman (1971). The authors assume that the market is composed of two to three operators which are in Cournot competition. Each operator $i=1,2,3$ is characterized by an interconnection fee $a_{i}$ (Flochel (1999), Harbord and Pagnozzi (2010)).

The operators agree on a common interconnection tariff $a_{1}=a_{2}=a_{3}=a$. The authors also assume that the two operators charge retail rates that are very close $\left(P_{1}=P_{2}=P\right.$

\footnotetext{
${ }^{3}$ Values are estimated using the equation $\vartheta=\frac{1}{n}$.
} 
). Let $P=1-Q=1-\left(q_{12}+q_{21}\right)$ the inverse demand function and the $Q$ total amount of exchanged traffic between the two networks.

In this model, there are two industrial configurations in the market, a private and a public operator. The first one maximizes his profit:

$$
\pi_{1}=\left(1-q_{12}-q_{21}-a\right) q_{12}+a q_{21}
$$

and the second operator maximizes the following function:

$$
\pi_{2}=\frac{1}{2}\left(q_{12}+q_{21}\right)^{2}+\left(1-q_{12}-q_{21}-a\right) q_{21}+a q_{12}
$$

If there is privatization of the incumbent operator, the duopoly market structure becomes then private.

The model assumes that there are $N$ operators on the Phone Market, who have the choice between colluding and competing. The incitation to collude will depend on the critical threshold of preference for collusion (C.T.P.C.) that is related to the discount factor $\delta$ of each operator. Each operator has to choose between two strategic behaviors: either competing or colluding, regarding to the comparison between short-term gains to deviate and long-term losses after deviation, in a repeated game. In such a context, collusion is possible (Debbichi and Hichri (2013a)) when the preference for the present, reflected by the discount rate $r$, (with $\delta=\frac{1}{1+r}$ and $0 \leq \delta \leq 1$ ) is very low (Friedman (1971)).

Players are concerned with an indefinitely repeated sequential game where in the first stage, at period $t=0$, they decide to collude. If they cooperate in period $t=1$, player $i$, where $i=1,2(N=2)$ realizes a profit equal to $\pi_{i}^{\text {Coll }}$. A unilateral deviation from collusion will change this profit to $\pi_{i}^{\text {Dev }}$, with $\pi_{i}^{\text {Dev }}>\pi_{i}^{\text {Coll }}$.

Debbichi and Hichri (2013a) suppose that a deviation of one player in period $t$ will be followed by a change in the cooperative behavior of the other operator in period $t+1$, such that the profit of each operator becomes equal to $\pi_{\mathrm{i}}^{\mathrm{Comp}}$, as both operators deviate from collusion. Calculations of the updated value of profit after Deviation $V^{\text {Dev }}$ and the updated value of profit after Collusion $V^{\text {Coll }}$ show that:

$$
V^{D e v}=\sum_{\mathrm{t}=1}^{\infty} \delta^{\mathrm{t}} \pi_{\mathrm{i}}^{\mathrm{Comp}}=\frac{\delta}{1-\delta} \pi_{\mathrm{i}}^{\text {Comp }}
$$

and

$$
V^{\text {Coll }}=\sum_{\mathrm{t}=1}^{\infty} \delta^{\mathrm{t}} \pi_{\mathrm{i}}^{\text {Coll }}=\frac{\delta}{1-\delta} \pi_{\mathrm{i}}^{\text {Coll }}
$$

Then, collusion is a better strategy if the profit resulting from Deviation, in a repeated game, is lower than the difference between the updated value of profit after Collusion and the updated value of profit after Deviation:

$$
\frac{\delta}{1-\delta}\left(\pi_{\mathrm{i}}^{\text {Coll }}-\pi_{\mathrm{i}}^{\text {Comp }}\right)>\pi_{i}^{\text {Dev }}-\pi_{i}^{\text {Coll }}
$$

From this inequality, Debbichi and Hichri (2013a) calculate the threshold of the discount factor $\bar{\delta}$ from which collusion becomes possible: 


$$
\delta>\bar{\delta}=\frac{\pi^{\mathrm{Dev}}-\pi^{\mathrm{Col}}}{\pi^{\mathrm{Dev}}-\pi^{\mathrm{Conc}}}
$$

Consequently, if the value of $\delta$ for one operator is higher than $\bar{\delta}$, collusion will be the best strategy to choose. Table 2 presents the different theoretical values of the critical threshold of preference for collusion, as calculated in Debbichi and Hichri (2013a), in different market structures.

Table 2: Value of the critical threshold of preference for collusion in different Market structures (Debbichi and Hichri (2013a))

\begin{tabular}{|c|c|}
\hline Duopoly with private operators & Oligopoly with three private operators \\
\hline $\bar{\delta}=\frac{\frac{1}{64}+\frac{1}{4} \mathrm{a}\left(\mathrm{a}-\frac{1}{2}\right)}{\frac{9}{64}+\frac{1}{4} \mathrm{a}\left(\mathrm{a}-\frac{1}{2}\right)-\frac{1}{9}(1+2 \mathrm{a})(1-\mathrm{a})}=\frac{9}{17}$ & $\bar{\delta}=\frac{\frac{3}{4} a^{2}-\frac{2}{3} a+3 / 54}{\frac{3}{4} a^{2}-\frac{2}{3} a+\frac{1}{9}+\frac{1}{16}(1-a) \cdot(1-3 a)}$ \\
\hline Duopoly with mixed operators & $\begin{array}{c}\text { Mixed oligopoly with a public operator and two } \\
\text { private }\end{array}$ \\
\hline $\bar{\delta}=\frac{\mathrm{a}^{2}+\mathrm{a}-\frac{3}{4}}{5 \mathrm{a}^{2}-3 \mathrm{a}+\frac{1}{4}}$ & $\bar{\delta}=\frac{3 \mathrm{a}^{2}+2 \mathrm{a}-\frac{5}{3}}{9 \mathrm{a}^{2}-4 \mathrm{a}+1 / 3}$ \\
\hline
\end{tabular}

As shown in Table 1, the critical threshold of preference for collusion is constant in a private duopoly and is equal to $\frac{9}{17}$. This result is similar to those found by Cortade (2005) in the case of internet operators.

The critical threshold of preference for collusion depends on the interconnection fees $a$. That's why Debbichi and Hichri (2013a) discuss then the variation of $\bar{\delta}$, the critical threshold of preference for collusion (C.T.P.C.) when the interconnection fees $a$ vary. A study of the regulated interconnect rates paid by entrants to incumbents can be found in Edwards and Waverman (2006). Another study related to Internet Interconnection is presented by Laffont et al. (2003).

\section{Application to different Arabian Market Structure:}

We propose to discuss in this section the variation of $\bar{\delta}$, when the interconnection fees $a$ vary, for each Arabian market structure between 1999 and 2008.

\subsection{Structure of some Arabian mobile phone Markets:}

\subsubsection{Algeria}


The Algerian mobile market structure was historically a public monopoly with one operator (Algeria Telecom). The first offer "GSM" (Global System for Mobile) was launched in 1999. Since 2001, a private operator, "Orascom Telecom Algeria," has entered on the mobile phone market. The first foreign private operator has commercially launched its brand "Djezzy" in February 2002.Finally, last arrived on the market, "Kuwait Wataniya Telecom" took its license in December 2003 and, six months later, created his brand "Nedjma." Since 2004, three operators are competing in the market for mobile phone in Algeria (see Table 3).

\subsubsection{Morocco}

The Moroccan mobile market structure was historically a public monopoly with one operator (Maroc Telecom). With the opening of postal and telecommunications competition a second mobile license of type "GSM" is authorized to (Médi Telecom) in 1999. Indeed, the privatization of (Maroc Telecom) (the historical national operator) in 2001 transformed (theoretically) the market from a mixed (Private-Public) duopoly to a private one. Finally, in 2010, a third private operator (Wana) joined the market to transform the duopoly private structure into a three private operators market (see Table 3 ).

\subsubsection{Jordan}

The Jordanian market structure has also experienced a profound change. Indeed, a second mobile license type "GSM" was launched in 1999. The privatization of the historical national operator in 2001 transformed (theoretically) the market from a mixed (PrivatePublic) duopoly to a private one. In 2009, a third private operator joined the market to transform the duopoly private structure into a three private operators market (see Table 3 ).

Table 3: The history of some Arabian mobile phone market structures from 1998 to 2010

\begin{tabular}{|c|c|c|c|c|}
\hline Years & Tunisia & Alegria & Jordan & Morocco \\
\hline $\mathbf{1 9 9 8}$ & Monopoly & Monopoly & Monopoly & Monopoly \\
\hline 1999 & $\checkmark$ & $\checkmark$ & Duo poly & Duo poly \\
\hline 2000 & $\checkmark$ & $\checkmark$ & Duo poly (priv) & $\checkmark$ \\
\hline 2001 & $\checkmark$ & $\checkmark$ & $\checkmark$ & Duo poly(Priv) \\
\hline 2002 & Duo poly & Duo poly & $\checkmark$ & $\checkmark$ \\
\hline 2003 & $\checkmark$ & $\checkmark$ & $\checkmark$ & $\checkmark$ \\
\hline 2004 & $\checkmark$ & Trio poly & $\checkmark$ & $\checkmark$ \\
\hline 2005 & $\checkmark$ & $\checkmark$ & $\checkmark$ & $\checkmark$ \\
\hline 2006 & Duo poly(Priv) & $\checkmark$ & $\checkmark$ & $\checkmark$ \\
\hline 2007 & $\checkmark$ & $\checkmark$ & $\checkmark$ & $\checkmark$ \\
\hline 2008 & $\checkmark$ & $\checkmark$ & $\checkmark$ & $\checkmark$ \\
\hline 2009 & $\checkmark$ & $\checkmark$ & Trio poly & $\checkmark$ \\
\hline 2010 & Trio poly & $\checkmark$ & $\checkmark$ & Trio poly \\
\hline
\end{tabular}




\section{2) Results and Discussion:}

In this section, and based on calculations made by Debbichi and Hichri (2013a) for the critical threshold of preference for collusion for several market structures, we propose to calculate this threshold in the case of Tunisia, Algeria, Morocco and Jordan. Since the (C.T.P.C.) depends on the interconnection fees $a$, the curves of Figures (1 to 5) are plotted along the values taken by the threshold function by changing the value of "a" each year.

As shown in Figure 1, the value of the critical threshold of preference for collusion (C.T.P.C) in Tunisia is increasing but negative during the period (2002-2006). From 2007, the year following the privatization of "Tunisia Telecom," the threshold becomes positive but remains constant. This is due to a transition from the mixed structure to the private market structure when the public operator "Tunisia Telecom" (T.T.) became private. In fact, in the Tunisian mobile market, we had between 2002and 2006:

$$
\pi_{i}^{\mathrm{Conc}}<\pi_{i}^{\mathrm{Dev}}<\pi_{i}^{\mathrm{Col}}
$$

and after 2006:

$$
\pi^{\text {Dev }}-\pi^{\mathrm{Col}}=\mathrm{k}\left(\pi^{\mathrm{Dev}}-\pi^{\mathrm{Comp}}\right) \quad \text { with } \mathrm{k}=\text { cte }
$$

As shown in Figure 2, in the Algerian Market, the value of the critical threshold of preference for collusion (C.T.P.C) is negative during the period 2002-2004. From 2004, the year of entry of a third operator, the threshold became positive (although this value is almost near to zero). This is due to a transition from the duopoly market structure to an oligopoly market structure.

In Jordanian and Moroccan market (respectively Figure 3 and Figure 4), the value of the critical threshold of preference for collusion (C.T.P.C), during the period 2002-2008, is decreasing, but remains positive and becomes constant. In both markets, the market structures are substantially the same.

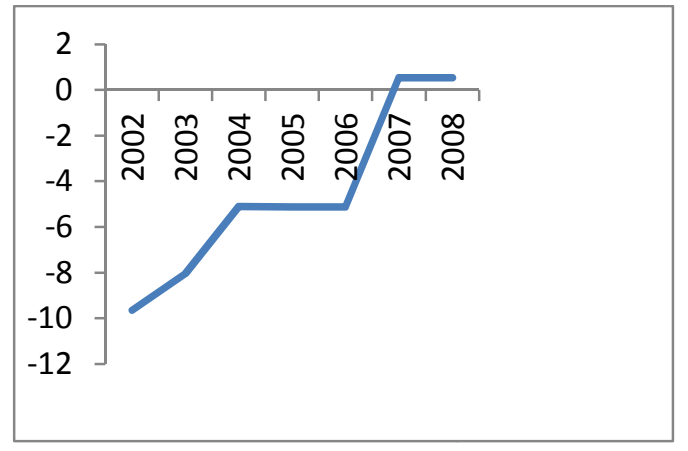

Figure1:Evolution of the Critical Threshold of Preference for Collusion in the Tunisian Market

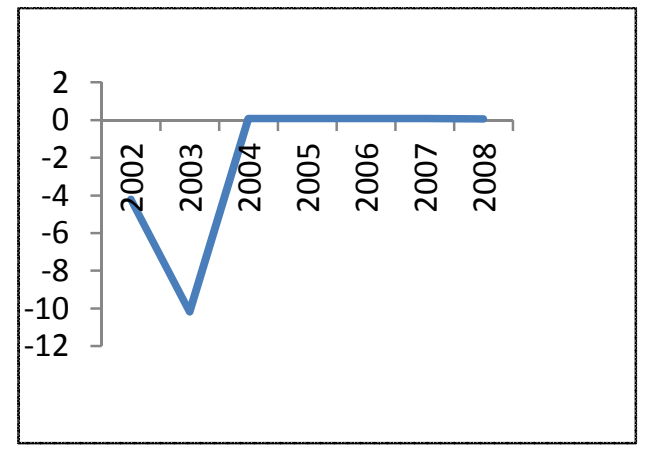

Figure2:Evolution of the Critical Threshold of Preference for Collusion in the Algerian Market 


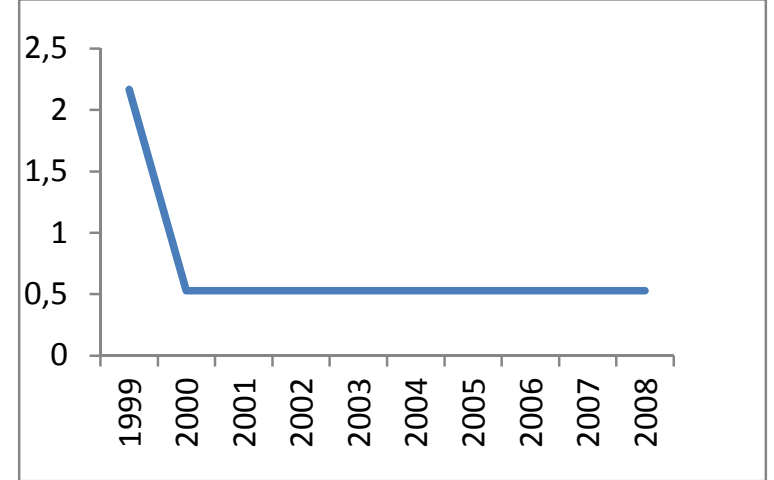

Figure3:Evolution of the Critical Threshold of Preference for Collusion in the Jordanian Market

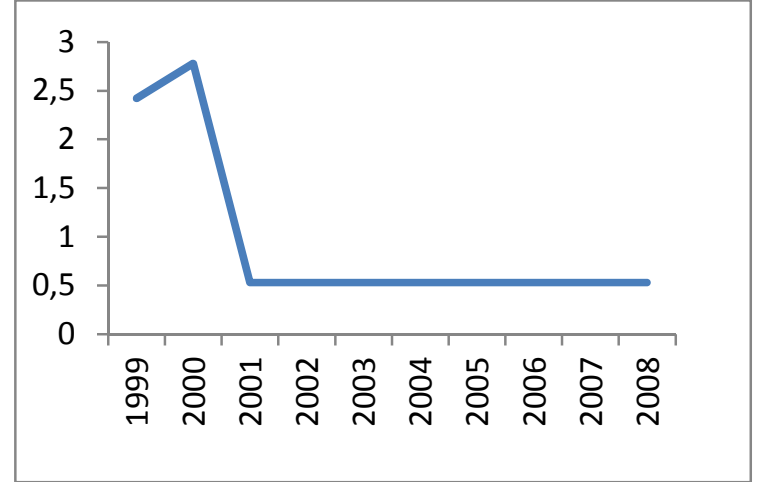

Figure4: Evolution of the Critical Threshold of Preference for Collusion in the Moroccan Market

If we compare the Tunisian case to the Algerian one, the value of the critical threshold of preference for collusion is higher during the period 1999-2007, in the Algerian market than its value in the Tunisian one (see Figure 5). After 2007, the two values are very similar, with a relatively higher value on the Tunisian market.

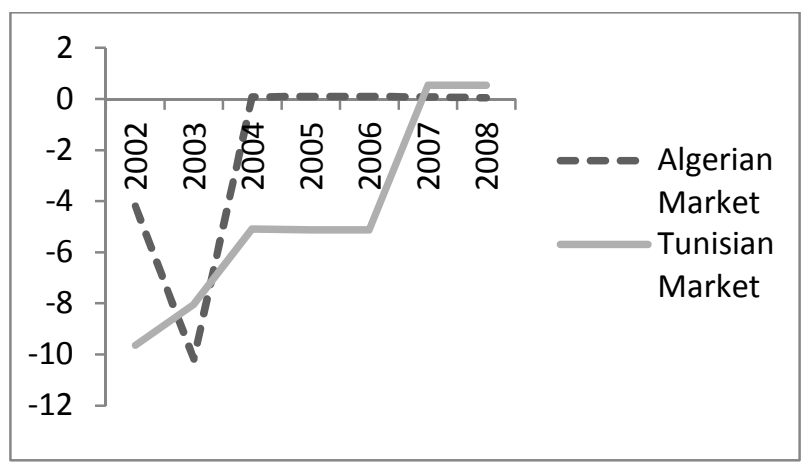

\section{Figure 5 : Comparing the critical threshold of preference for} collusion in the Tunisian and Algerian Market

The comparison of the value of the critical threshold of preference for collusion for the four studied countries allows us to conclude that collusion is easier on the Tunisian market, than on the Algerian, Jordanian, or Moroccan one. This result is logical, as the market for mobile phone in Algeria is more competitive (oligopolistic) during the period of study, in comparison to its Tunisian counterpart. The entry of a third operator on the Algerian market was in 2004, whereas it was the case in Tunisia only in (2010).

Obviously, there is a relationship between the number of competitors on one market and collusion, as shown in Selten (1973) who presents a theory that investigates "the connection between the number of competitors and the tendency to cooperate." 


\section{Concluding remarks:}

We characterized in this paper the state of mobile phone market in Tunisia, Algeria, Morocco and Jordan through the comparison of the level of the critical threshold of preference for collusion. This comparison is based on the market power of operators on interconnection markets, using the Lerner index. This index is a relevant indicator available for the regulator to judge the nature of competition. To keep a certain degree of competition, the regulator, as in Flacher and Jennequin (2007), can set the level of interconnection rate at a level that minimizes collusion. The regulator can control market structure to minimize prices. The "conduct parameter" measuring the intensity of competition is not null during the period (1993-2011), which means that interconnection prices are not oriented to marginal cost and that mobile phone operators practice market power. In fact, operators can maintain these high interconnection charges to inflate prices paid by consumers and reduce the probability of detecting collusion retail prices. Results show that collusion is easier on the Tunisian market that on the Algerian, Jordanian, and Moroccan one. A possible extension of our work could lead us to estimate the "conduct parameter" depending on variables related to market structures and prices.

\section{References}

Artz, B., Heywood, J. and Mc Ginty, M., (2009) “The merger paradox in a mixed oligopoly," Research in Economics, vol. 63, pp. 1-10.

Baranes, E. and Flochel, L., (1999): "Interconnexion de réseaux et qualité de linfrastructure comme barrière à l'entrée : Quels Instruments de Régulation," Recherches Economiques de Louvain, vol. 65(1), pp. 23-46.

Baranes, E. and Poudou, J.C., (2010): "Cost-based access regulation and collusion in a differentiated duopoly," Economics Letters, vol. 106, pp. 172-176.

Berger, U. (2005) «Bill-and-keep vs. cost-based access pricing revisited» Economics Letters, vol.86, pp 107.112

Bourreau, M (2001) «La boucle locale radio comme vecteur d'entrée dans les télécommunications,» Revue Française d'Économie, Programme National Persée, Vol.15(4), pages 111-143.

Bulatovic, V., (2004): "Les Enjeux Economiques de l'Interconnexion des Réseaux de Télécommunications," Thèse de Doctorat, Université d'Orléans.

Colombier, N., MChirgui, Z. and Pénard, T., (2010): "Une analyse empirique des stratégies d'interconnexion des opérateurs internet," Journal d'économie industrielle, vol. 131, pp. 2550 .

Cortade, T. (2005), «Règlementation, Structures de Marché et Comportements Stratégique Sur le Marché de l'Internet, » Doctorat thesis, University of Montpellier.

De Donder, Ph. (2005), «L'entreprise publique en concurrence : les oligopoles mixtes, » Revue française d'économie, vol. 20, ${ }^{\circ}$ 2, pp. 11-50.

Debbichi (2014): "Market Power and Competition Effect on Termination Rate: Econometric Analysis of the Tunisian Case," Research in Applied Economics, Vol. 6, no. 1, p.p.166-175. 
Debbichi, S. et Ben Khalifa, A. (2013), "Market Conduct, interconnection costs and benchmarking in mobile phone industry: the Tunisian case," International Journal of Mobile Learning and Organisation, vol. 7, $\mathrm{n}^{\circ}$ 1, pp. 1-13.

Debbichi, S. et Hichri, W. (2013a), "Threshold of Preference for Collusion and Interconnection Fees in Different Market Structures : the Tunisian Mobile Market Case, » Working Paper GATE n ${ }^{\circ}$ 2013-07.

Debbichi, S. et Hichri, W. (2013b), «Collusion et structure des coûts dans un marché de duopole mixte vs privé de téléphonie mobile,» Working Paper GATE n 2013-19.

Dessein, W. (2003) « Network competition in nonlinear pricing» RAND Journal of Economics, Vol. 34, No 4, pp. 593-611.

Edwards, G. and Waverman, L. (2006) «The Effects of Public Ownership and Regulatory Independence on Regulatory Outcomes,» Journal of Regulatory Economics, vol. 29(1), p.p. 23-67, 01.

Flacher, D. et Jennequin, H. (2007), « Réguler le secteur des Télécommunications ? Enjeux et perspectives, »ed. Economica.

Flochel, L., (1999): "Interconnexion de Réseaux et Charges daccès : Une Analyse stratégique," Annales d'économie et de statistique, vol. 53, pp. 171-196.

Friedman, J. (1971), "A non-cooperative equilibrium for supergames", Review of Economic Studies, vol. 38 (1), pp. 1-12.

Harbord and Pagnozzi (2010): "Network-Based Price Discrimination and 'Bill-and-Keep' vs. 'Cost-Based' Regulation of Mobile Termination Rates," Review of Network Economics, Vol. 9, No. 1, p.p. 1-46.

Hoffler, F. (2009) « Mobile Termination and collusion, Revisited,» Journal of Regulatory Economics, vol. 35, pp. 246-274.

Murakami, H. and Asahi, R. (2011) «Multimarket contact and Market Power: A case of The U.S Airline Industry,» Hitotsubashi Journal of Commerce and Management, 45, pp.81-88.

Laffont, J.J Marcus, S. Roy, P. Tirole, J. (2003) «Internet Interconnection and the Off-net Cost Pay Principle,» The RAND Journal of Economics, vol. 34, n², p.p. 370-390.

Laffont, J.J. and Tirole, J. (2002) « Competition in Telecommunications,» European Journal of Political Economy, Vol.18, Issue 3, p.p. 609-610.

Laffont, J.-J. and Tirole, J., (2000): "Competition in Telecommunications," MIT Press, Cambridge.

Laffont.J.J. Tirole. J, Geras, I. (1996) «Creating competition through interconnection: Theory and practice» Journal of Regulatory Economics.

Parker, P.M. and Roller, L-H. (1997) « Collusive conduct in duopolies: multimarket contact and cross-ownership in the mobile telephone industry» RAND Journal of Economics, Vol. 28 ,

Parsons, S.G. (2002) «Laffont and Tirole's competition in Telecommunications: A view from the US» Int.J.of the Economics of Business, vol.9, No.3, pp.419-436

Pénard, T. (2003) «Structures du marché et pratiques facilitant la collusion : une approche par la théorie des jeux répétés» Économie rurale, Vol. 277, No 277-278, pp. 80-98. 
Pénard, T. (2002), "Competition and Strategy on the Mobile Telephony Market : a Look at the GSM Business Model in France", Communication \& Strategies, n45, pp. 49-79.

Schiff, A.F. (2005), «Three Essays in Network Economics: Two-Way Interconnection, TwoSided Networks, and Reputation Systems», Doctorat Thesis, University of Auckland.

Selten, R.(1973) «A simple model of imperfect competition, where 4 are few and 6 are many,» International Journal of Game Theory, Vol. 2, Issue 1, pp 141-201.

Souam S. et Pénard, T. (2002) «Collusion et politique de la concurrence en information asymétrique» Annales d'Économie et de Statistique, nº6, pp. 209-233.

Wallsten, S. J (2001) «An Econometric Analysis of Telecom Competition, Privatization, and Regulation in Africa and Latin America» The J. of Industrial Economics Volume X XLIX $\mathrm{N}^{\circ} .1(2001)$

Wallsten, S.J. (2002) « Does Sequencing Matter? Regulation Privatization in Telecommunications Reforms» Policy researches Working Paper, $\mathrm{n}^{\circ} 2817$, 